\title{
Coexistence With LeSter EMBRee
}

\section{Coexistencia con Lester EMbree}

\author{
Wataru Wada \\ Hannan University, Osaka \\ wwataru1224@coral.plala.or.jp
}

I met Lester Embree for the first time in Freiburg, where an international phenomenological conference was being held. More than 30 years have passed since then. I encountered him while rambling through a park during a break from the conference. We caught each other's eye, sat on a bench, and talked for a while. He gave the strong impression of being a dedicated researcher.

My last chance to talk with him was at the Organization of Phenomenological Organizations conference in December 2014, in Perth, Australia. It was a long time since I had last seen him, but it certainly didn't feel that way. Lester, a tall man, had filled out somewhat and, standing there with his huge frame, he really came across as a "philosopher". He was as goodnatured as I'd remembered him. When I asked him if he hadn't put on a little too much weight, I saw in his eyes a moment of resigned sadness, which was a clear sign of his anxiety about his health. He told me that he had started going to the gym regularly, which was one of the numerous instructions of his doctor.

It was in 2004 that I begun to translate his book, Reflective Analysis, into Japanese, with Sung Tae Lee. In the course of this translation, Lester kindly 
replied to many questions I posed by e-mail. At the international conference in Tokyo, I got to understand the meaning of sentences that were unclear to me by talking with him in person. It seemed to me that he had imagined the translator of his book to be the stiff and starchy type. But that changed when he met me at that time. He told me he'd been nervous about meeting someone he didn't know, but was relieved to be able to have a relaxed talk. Clearly he had forgotten that encounter in Freiburg with the unknown graduate student.

I asked him numerous questions on that occasion, and he readily altered wordings without any hesitation, saying, "How about this?", or "OK, I'll delete this expression", "Is it more understandable if I change this phrase like so?". He emphasized the understandability of the content over his pride as a writer, so didn't mind altering how he expressed things at all. This was my first experience of seeing an original text being changed right in front of me. I was really, profoundly astonished by just how flexible he was toward his book. Of all my communication with Lester, I will never forget this exceptional experience.

I would like to refer to this book, which is filled with personal memories for me. As you know, it is written for teachers interested in phenomenology to put it to practical use in the classroom. A distinguishing feature of the book is how at the end of each chapter Lester added exercises to help students understand what was taught in the classroom. These exercises can be a good beginning for them to think through phenomenological problems for themselves. Phenomenology is nothing but a trial to grasp the meaning of events that develop not only in front of and inside one, but also in the world at large and in one's relations with others. Lester hoped each student would conduct that trial in his or her own way. Entering into his intention, I translated his book Reflective Analysis into Japanese with the title "Phenomenology Executed".

Even though the book was written for a general readership, the author's main concern was to get students to think by themselves in conformity with things themselves. For that purpose relatively understandable expressions are chosen and explained with respect to daily, concrete situations. The 
description of the scene of eating together at a restaurant is an excellent example of clear explanation. Readers of these descriptions will be inspired by the unanticipated attractiveness of phenomenology. This book has been translated into more than 10 languages because of Lester's clear writing about concrete situations.

The central message of this book is nothing other than an invitation to "look at things themselves carefully". This slogan which Husserl considered a crucial point of his phenomenology is still the go-to one when explaining the approach even 80 years after his death. However, we could say that the number of those who take up Husserl in turning to "things themselves" is decreasing year by year. Rather, philological research that tries to read deeply into his original texts is on the increase. Research results using difficult technical terms are published day by day here and there throughout the world. But the number of readers willing to pore over such specialized research is limited. The gap between specialists and amateurs is constantly widening. Lester objected to the excesses of philological studies and insisted upon our returning to things themselves once again. He believed that unfenced space for free discussion among anybody can be created if those involved equally turn to things themselves. I agree with his straightforward conviction.

However, it is not so easy to return to things themselves. It might be far easier to grapple with philological studies. We don't have much difficulty in collecting a topic in one paper based upon close reading of Husserl's original text. But it is difficult to look at things themselves, just as Husserl himself did and it is also difficult to describe things themselves by grasping the nature not only of looking acts but also of things looked at by those acts. Even though things themselves are ordinarily experienced by everybody, we need to pay attention to what is happening in our daily lives and we have to articulate our streaming experience in order to think of the state of the encounter with things themselves. Rainer Maria Rilke wrote about learning to see in his book Die Aufzeichnungen des Malte Laurids Brigge. As he insists, learning to see is nothing other than starting to face things themselves and to think according to them. 
What Lester calls reflective analysis is a trial whose theme is nothing but things themselves. The analysis is carried out based on a consideration and description of those things. Through reflection, such experiences are objectified as perceptions of something, picturing to ourselves a scene in our mind, remembering past events, expecting what will happen in the future, and so on. We need to carefully observe in order to describe each state of such various experiences and of phenomena encountered in them. First of all, we have to observe and to reflect attentively on what is happening in front of us in the course of our conscious experiences. Then the acts of analysis and description themselves can be explored, substantiated by things themselves. Lester's Reflective Analysis is an extremely fruitful result of his elaboration of activity.

By reading this book carefully, readers will understand the nature of reflective analysis. At first sight, phenomenology can seem like a science filled with difficult technical terms. But phenomenology yields attractive results by changing our approach to science. Lester was very much a person who showed us the genuine attractiveness of phenomenology. With his book, we can learn to look not only at ourselves and others, but also concrete events in this world we live in. Closer observations lead to deeper thinking, which contributes to opening up new horizons in life.

Lester is now an inhabitant of an invisible world, and in my mind he looks out on this visible world with a bashful smile. To live is on the one hand to communicate with others in this world, but on the other to co-exist with those whom we are unable to perceive any more. The time I could share with Lester will never cease to reverberate in my mind. 